\title{
建物屋根面の日射反射性能向上による ヒートアイランド緩和効果 \\ REDUCTION OF SENSIBLE HEAT EMISSION BY INCREASING ROOF SOLAR REFLECTANCE AS A COUNTERMEASURE OF HEAT ISLAND PHENOMENA
}

\author{
近藤靖 史*, 小笠原 岳**, 大木泰祐 ${ }^{* *}$, 有働邦広**** \\ Yasushi KONDO, Takeshi OGASAWARA, Taisuke OHKI \\ and Kunihiro UDOH
}

\begin{abstract}
The mean air temperature in urban areas has risen due to a change of urban structure in a long term. High reflective paints can reduce a cooling load of buildings and can also improve the thermal environment in urban areas. In this paper, field measurements were carried out in a building where two areas of rooftop were finished with high reflective paint and ordinary paint. Then, the heat flux on the urban surface was calculated on the basis of heat budget equation with measured data, and the result was compared with the artificial heat release from buildings in 23 wards of Tokyo. The results of this paper show that high reflective paint is effective to resolve heat island problem. On the other hand, short wave radiation reflected at high reflective roofs may increase cooling load of neighbor buildings. In this paper, the coupled simulations of radiation and convection around buildings were conducted to estimate the influence of solar reflection at roofs on surrounding building walls. The results show that short wave radiation from high reflective roofs to neighbor building walls is much smaller than direct radiation from sun and sky to walls.
\end{abstract}

Keywords: High Reflective Paint, Heat Island, Heat Budget Analysis, CFD Simulation 高反射率塗料，ヒートアイランド，熱収支解析，CFD 解析

\section{1 序}

近年、都市における人工排熱の増加や、舗装面および建築物増加 による都市被覆の変化、都市形態の変化による都市内部の弱風化な どにより、都市の平均気温は上昇傾向にある。その結果、都市の気 温が都市周辺より高温となるヒートアイランド現象が引き起こされ ている。ヒートアイランド現象は、夏期における熱污染であり、都 市における生活の快適性を著しく損なうと共に、外気温の上昇によ り冷房負荷が増加し、建物冷房用消費エネルギーの増大を招く。ま た、消費エネルギー増大により、人工排熱量が増大寸るため、都市 の気温をより一層上昇させるという悪循環を形成している。このよ うなヒートアイランド現象を抑制する手法として以下が挙げられる。 すなわち、都市被覆の日射反射率を上げ、昼間において建物躯体や 道路への蓄熱を抑えることができる高反射率塗料の屋根面・舗装面 への適用や、日射熱を蒸発潜熱として変化させて顕熱放散量を削減 することができる緑化や保水性材料の使用、建物配置等を考慮して 川風・海風を積極的に取り入れるなどの対策が考えられる。

本研究では、ヒートアイランド現象の緩和対策として、都市表面
における日射受熱量を減少させ、都市大気を暖める顕熱放散量を削 減する効果が期待できる建物屋根面の日射反射性能の向上(図 1 参 照について検討を行う。

既往の研究では、高反射率塗料を建物屋根に塗布し、夏期におけ

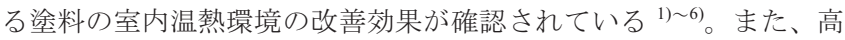
反射率塗料は、室内冷房負荷軽減だけでなく、反射日射量を増加さ せ、その結果、屋根面における顕熱放散量が減少し、都市の気温上 昇の抑制に有効であると考えられる。

本報では、建物屋根面の日射反射性能の向上による効果を実測お

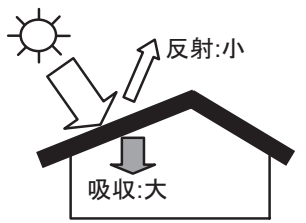

(a) 一般的な屋根

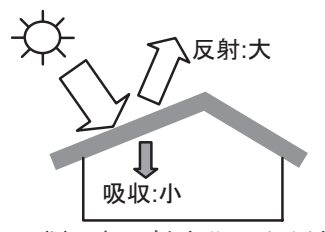

(b) 高反射率化した屋根
図 1 建物屋根面の日射反射性能向上の概念
* 武蔵工業大学工学部 教授·博士 (工学)

** 東京理科大学工学部 嘱託助教·博士 (工学) (研究当時, 武蔵工業大学工学部 客員研究員)

** 大成建設侏) 修士 (工学) (研究当時, 武蔵工業大学大学院 博士前期課程)

**** 武蔵工業大学大学院 博士前期課程
Prof., Faculty of Engineering, Musashi Institute of Technology, Dr. Eng. Assistant Prof., Tokyo University of Science, Dr. Eng.

(Visiting Researcher, Faculty of Eng. Musashi Institute of Technology) Taisei Corporation, M. Eng.

(Formerly Graduate Student, Musashi Institute of Technology)

Graduate Student, Musashi Institute of Technology 
よび熱収支解析により検討する。まず、建物屋根に高反射率塗料 および一般叙料(ここでは、通常市販されている日射反射性能を向 上させていない塗料を指す。) を塗布し、熱的性能を把握するため の実測を行う。次に実測結果と屋根面の熱収支式により、屋根面か ら都市大気への顕熱放散量を試算し、屋根面の日射反射性能向上に よる効果を検討する。また屋根面に高反射率塗料を塗布した場合、 屋根面で反射した日射が隣接建物壁面に吸収され、熱負荷の増大が 懸念される。そこで本報では CFD 解析を用いて屋根面で反射する 日射による隣接建物壁面の熱負荷について検討する。

\section{2 高反射率塗料および一般塗料の熱的性能に関する夏期実測}

ここでは、高反射率塗料を塗布し、日射反射性能を向上させた屋 根について温度や放射熱収支の実測を行い、一般狳料を塗布した屋 根と比較する。

\section{1 夏期実測概要}

東京都世田谷区に位置する武蔵工業大学講義棟(8 号館)屋上にお いて高反射率塗料および一般塗料を屋根表面に塗布し、最上階であ る 4 階教室の室内温熱環境および屋上の屋外温熱環境の実測を夏期 に行った。使用した各塗料の分光反射率注1)を表 1 および図 2 に、 また実測対象建物の概要を表 2 に、4 階および屋上階平面図を図 3 に示寸。塗料は教室 $\mathrm{A}$ の屋上部分に一般塗料を、教室 $\mathrm{B}$ の屋上部 分に高反射率塗料を塗布した(写真 1 参照)。

\section{2 測定項目および測定位置}

測定項目および測定位置などを表 3 に示す。測定は 2005 年 8 月 1 日から 8 月 24 日にかけて実施した。4 階教室は屋上スラブとの間 に約 $800 \mathrm{~mm}$ の屋根裏空間があり、この屋根裏内の温度も測定した。 教室の空は全閉とし、白色のカーテンを閉め切り、換気を行わない 状態で測定を実施した。なお対象建物の竣工は古く、屋上の構造は 屋上スラブの上に防水層があるのみで、断熱材は施されていない。

\section{3 実測結果および考察}

実測期間中の晴天日を選び、これを代表日として検討する。検討 に用いた代表日の全天日射量および外気温の日変化を図 4 に、風速 を図 5 に示す。測定代表日は 2005 年 8 月 20 日とした。当日の最高 気温は $35.7^{\circ} \mathrm{C}$ 、最低気温は $27.6^{\circ} \mathrm{C}$ 、日積算日射量は $24.1 \mathrm{MJ} / \mathrm{m}^{2}$ であ った。

\section{(1) 屋上表面温度(図 6 参照)}

屋上表面温度を図 6 に示す。高反射率塗料を塗布した屋上表面温 度は一般塗料を塗布した屋根面と比較して最大約 $10^{\circ} \mathrm{C}$ 低く、日中 の温度上昇が大きく抑制されている。また夜間から朝方にかけての 屋上表面温度は高反射率塗料を塗布した屋根面が $1{ }^{\circ} \mathrm{C}$ 程度低くなっ ている。このように屋根面に高反射率塗料を塗布した場合、日中は 表面温度上昇が抑制されると同時に、建築躯体への蓄熱が低減され、

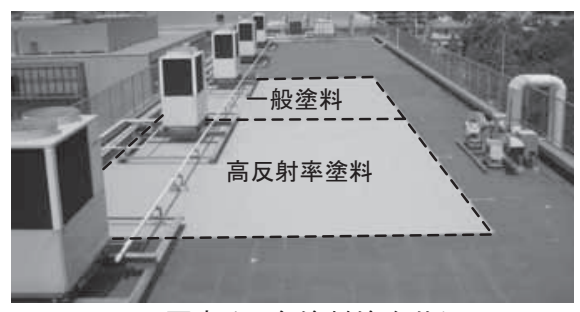

写真 1 各塗料塗布状況
表 1 各塗料の反射率注 11

\begin{tabular}{|c|c|c|c|c|c|c|c|}
\hline \multicolumn{2}{|c|}{ 塗料種別 } & \multicolumn{2}{|c|}{\begin{tabular}{|c|} 
日射反射率 \\
$(300 \sim 2100 \mathrm{~nm})$ \\
{$[\%]$} \\
\end{tabular}} & \multicolumn{2}{|c|}{$\begin{array}{c}\text { 可視光反射率 } \\
(380 \sim 780 \mathrm{~nm}) \\
{[\%]} \\
\end{array}$} & $\begin{array}{c}\text { 赤外反射率 } \\
(780 \sim 2500 \mathrm{~nm}) \\
{[\%]} \\
\end{array}$ & $\begin{array}{c}\text { 長波放射 } \\
\text { 率[\%] }\end{array}$ \\
\hline \multicolumn{2}{|c|}{ 高反射率塗料 } & \multicolumn{2}{|c|}{54.3} & \multicolumn{2}{|c|}{31.6} & 71.4 & 85.0 \\
\hline \multicolumn{2}{|c|}{ 一般塗料 } & \multicolumn{2}{|c|}{24.7} & \multicolumn{2}{|c|}{30.3} & 20.7 & 90.0 \\
\hline \multicolumn{8}{|c|}{ 表 2 実測対象建物概要 } \\
\hline \multicolumn{2}{|c|}{ 測定対象 } & \multicolumn{6}{|c|}{ 武蔵工業大学授業棟 8 号館 屋上、 } \\
\hline \multicolumn{2}{|c|}{ 主構造 } & \multirow{2}{*}{\multicolumn{6}{|c|}{$\begin{array}{c}\mathrm{RC} \text { 造 } \\
\left.9.6[\mathrm{~m}] \times 8.6[\mathrm{~m}]=81.6\left[\mathrm{~m}^{2}\right](\text { 各教室 }) 、 48.0\left[\mathrm{~m}^{2}\right] \text { (廊下 }\right)\end{array}$}} \\
\hline \multicolumn{2}{|c|}{ 床面積 } & & & & & & \\
\hline \multirow{2}{*}{\multicolumn{2}{|c|}{$\begin{array}{c}\text { 天井高 } \\
\text { 階高 } \\
\end{array}$}} & \multicolumn{6}{|c|}{$3.2[\mathrm{~m}]$} \\
\hline & & \multicolumn{6}{|c|}{$4.0[\mathrm{~m}]$} \\
\hline \multicolumn{8}{|c|}{ 表 3 測定項目および測定位置 } \\
\hline 測定項目 & \multicolumn{4}{|c|}{ 測定位置 } & $\begin{array}{l}\text { 測定 } \\
\text { 点数 }\end{array}$ & \multicolumn{2}{|c|}{ 計測機器 } \\
\hline \multirow{4}{*}{ 表面温度 } & \multicolumn{2}{|c|}{ 屋上 } & \multicolumn{2}{|c|}{ 屋上表面 } & $\begin{array}{l}1 \text { 塗料当 } \\
\text { り } 2 \text { 点 }\end{array}$ & \multicolumn{2}{|l|}{$\mathrm{T}$ 型熱電対 } \\
\hline & \multirow{3}{*}{\multicolumn{2}{|c|}{4 階教室 }} & \multicolumn{2}{|c|}{$\begin{array}{l}\text { 屋上スラブ } \\
\text { 下端表面 }\end{array}$} & $\begin{array}{l}1 \text { 教室当 } \\
\text { り } 2 \text { 点 }\end{array}$ & & \\
\hline & & & $\begin{array}{l}\text { 室内側 } \\
\text { 天井面 }\end{array}$ & & $\begin{array}{l}1 \text { 教室当 } \\
\text { り } 2 \text { 点 }\end{array}$ & $\begin{array}{l}\text { 有線小型温湿) } \\
\text { (TR-72, T\&D) }\end{array}$ & \\
\hline & & & 床面 & & 計 1 点 & & \\
\hline & & 尼上 & $\begin{array}{l}\text { FL+100, } \\
1,100 \mathrm{~mm}\end{array}$ & & $\begin{array}{l}1 \text { 塗料当 } \\
\eta 1 \text { 点 } \\
\end{array}$ & $\mathrm{T}$ 型熱電対 & \\
\hline 空気温度 & & & $\mathrm{FL}+1,10$ & Omm & $\begin{array}{l}1 \text { 教室当 } \\
\text { り } 1 \text { 点 }\end{array}$ & & \\
\hline & 4 階 & 㩆至 & 屋根裏? 裔 & & $\begin{array}{l}1 \text { 教室当 } \\
\text { り } 1 \text { 点 }\end{array}$ & $\begin{array}{l}\text { 無線小型温湿庄 } \\
\text { (RTR-53, T\&D) }\end{array}$ & \\
\hline & 4 階 & 廊下 & $\mathrm{FL}+1,10$ & Omm & 計 1 点 & & \\
\hline グローブ & & 屋上 & $\mathrm{FL}+1,10$ & $\mathrm{~mm}$ & 計 1 点 & グローブ球、 & \\
\hline 温度 & 4 階 & 教室 & $\mathrm{FL}+1,10$ & mm & 計 1 点 & $\begin{array}{l}\text { 無線小型温湿序 } \\
\text { (RTR-53, T\&D) }\end{array}$ & \\
\hline & & 尼上 & $\begin{array}{l}\text { 屋上ス } \\
\text { 屋外側表 }\end{array}$ & & $\begin{array}{l}1 \text { 塗料当 } \\
\text { り } 1 \text { 点 }\end{array}$ & & \\
\hline 熱流 & & & $\begin{array}{l}\text { 屋上ス } \\
\text { 室内側表 }\end{array}$ & & $\begin{array}{l}1 \text { 教室当 } \\
\text { り } 1 \text { 点 }\end{array}$ & 熱流計(MF-180, & 起䉼精㙨) \\
\hline & 4 階 & 教至 & $\begin{array}{l}\text { 室内側 } \\
\text { 天井面 } \\
\end{array}$ & & $\begin{array}{l}1 \text { 教室当 } \\
\text { り } 1 \text { 点 }\end{array}$ & & \\
\hline 放射量 & & 圣上 & $\mathrm{FL}+350 \mathrm{~m}$ & & $\begin{array}{l}1 \text { 塗料当 } \\
\text { り } 1 \text { 点 }\end{array}$ & $\begin{array}{l}\text { 長短波放射計 } \\
\text { (MR-50, 英弘精係 }\end{array}$ & \\
\hline $\begin{array}{c}\text { 外気 } \\
\text { 温湿度 }\end{array}$ & & 层上 & $\begin{array}{l}\mathrm{FL}+1,50 \\
(\text { 日影部) }\end{array}$ & & 計 1 点 & $\begin{array}{l}\text { 無線小型温湿 } \\
\text { (RTR-53, T\&D) }\end{array}$ & \\
\hline 風向・風速 & & E上 & $\mathrm{FL}+5,00$ & $0 \mathrm{~mm}$ & 計 1 点 & 超音波風速計(FT & 02, FT) \\
\hline 日射量 & & 屋上 & $\mathrm{FL}+0 \mathrm{mn}$ & & 計 1 点 & 日射計 (MS80 & 英弘精機) \\
\hline
\end{tabular}

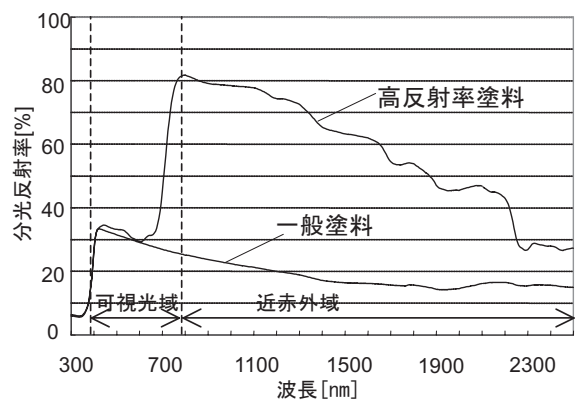

図 2 各塗料の分光反射率

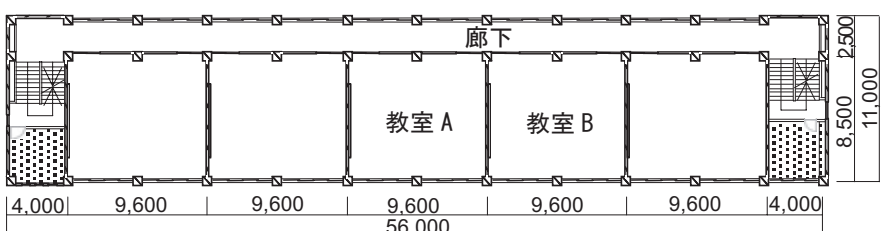

(a) 4 階平面図

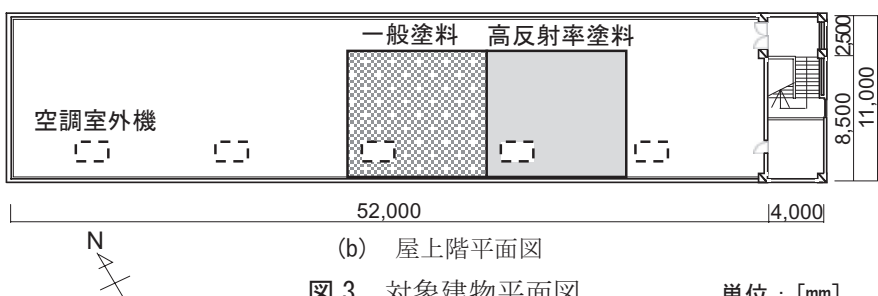

図 3 対象建物平面図

単位: [mm] 


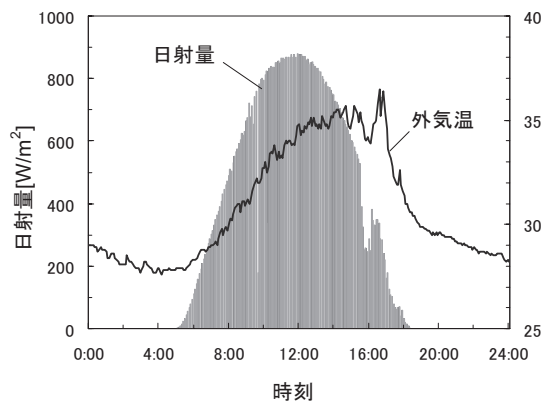

図 4 全天日射量·外気温

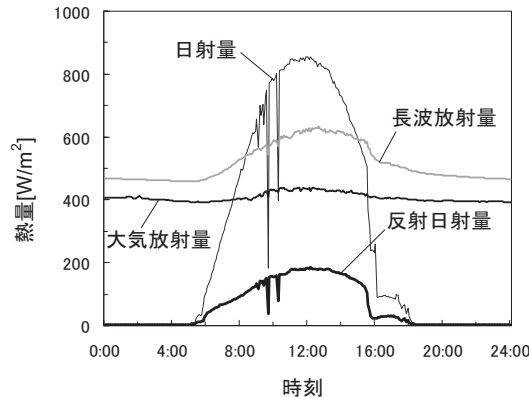

図 7 屋上面放射熱収支(一般塗料)

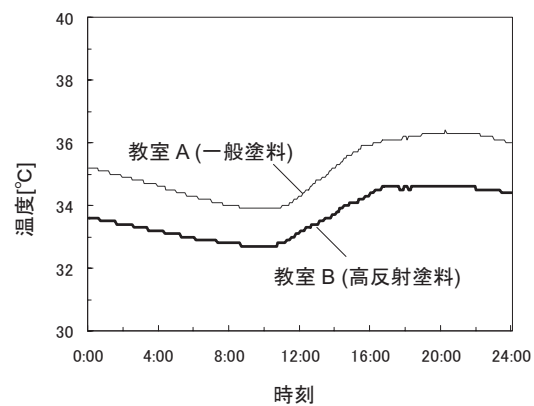

図 10 屋根裏空気温度

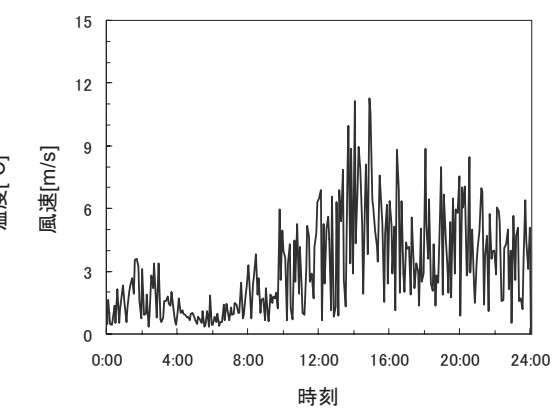

図 5 風速

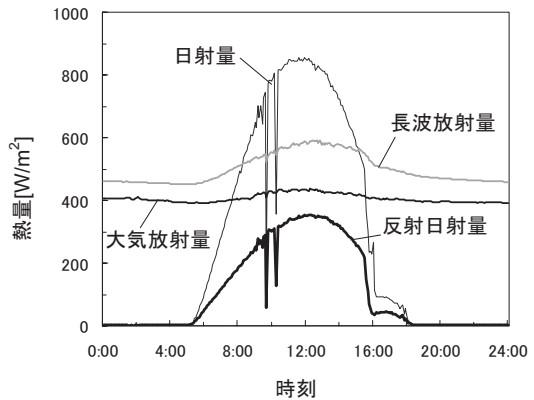

図 8 屋上面放射熱収支(高反射率塗料)

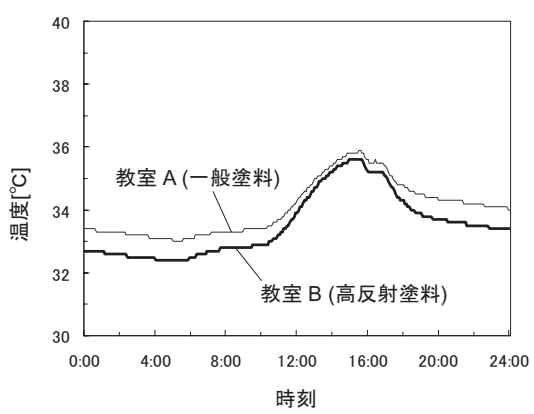

図 11 教室空気温度

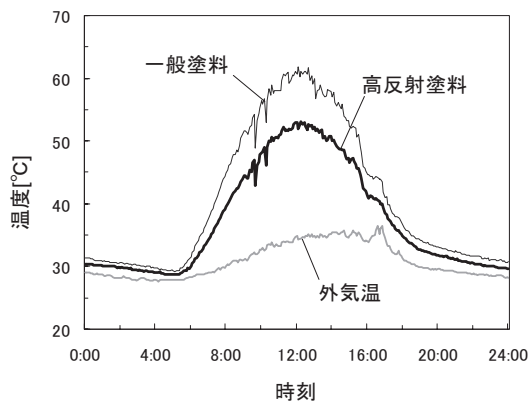

図 6 屋上表面温度

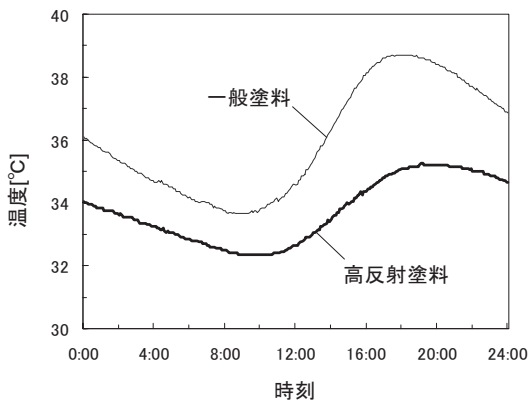

図 9 屋上スラブ下端表面温度

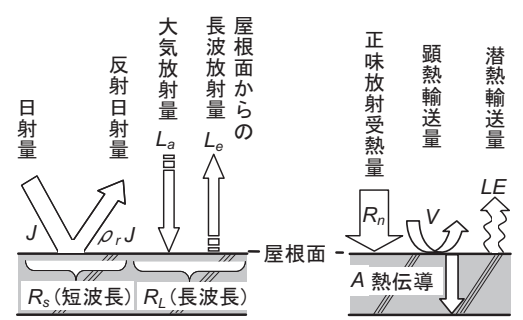

(a) 放射収支 $\quad$ (b) 熱収支

図 12 熱収支の概念図
日没後においても表面温度を低く保つことができる。なお、屋上表 面温度は一日を通して外気温より高い。また屋上表面温度のピーク は 12 時 30 分頃であるのに対し、外気温は 12 時 30 分を過ぎても上 昇している。

\section{（2）屋上面放射熱収支(図 7、8 参照)}

一般塗料を塗布した屋上面の放射熱収支を図 7 に、高反射率塗料 を塗布した屋上面の放射熱収支を図 8 に示寸。高反射率塗料を塗布 した屋上面の反射日射量は、一般塗料を塗布した屋上面に比べ大き い。また、図 6 で示したように高反射率塗料を塗布した屋上面は一 般塗装表面より温度が低くなるため、長波放射量は一般塗装表面よ り小さい。

\section{(3) 屋上スラブ下端表面温度(図 9 参照)}

屋上スラブ下端表面温度(屋上スラブ室内側表面温度)を図 9 に示 す。屋上面に一般塗料を塗布した教室 $\mathrm{A}$ と高反射率塗料を塗布し た教室 $\mathrm{B}$ における表面温度を比較すると、正午において約 $1.5^{\circ} \mathrm{C}$ 、 高反射率塗料を塗布した教室 B の方が低い。教室 A と教室 B での 表面温度差の最大は蓄熱による時間遅れの影響により 16 時 30 分こ ろに現れ、その差は約 $3.9^{\circ} \mathrm{C}$ である。このことからも高反射率塗料 を塗布したことで日中の日射熱吸収を抑え、建築躯体への蓄熱が低 減していることがわかる。

(4) 屋根裏空気温度(図 10 参照)
屋根裏空気温度を図 10 に示す。教室 A と教室 B の屋根裏空気温 度の変化は屋上スラブ下端表面温度変化と概数対応しており、高反 射率塗料を塗布した教室 B の方が終日低い值となった。しかしそ の差は $0.4 \sim 0.8^{\circ} \mathrm{C}$ とれほど大きくない。

(5) 教室空気温度(図 11 参照)

教室空気温度を図 11 に示す。教室 $\mathrm{A}$ と教室 $\mathrm{B}$ の温度差は小さく、 日中は $0.2 \sim 0.4^{\circ} \mathrm{C} 、$ 日没後は $0.5 \sim 0.7^{\circ} \mathrm{C}$ 程度であった。

\section{3 屋根面における熱収支解析}

高反射率塗料は都市の土地被覆の変化や人工排熱の増加により生 じたヒートアイランド現象の緩和に効果があると考えられる。また 都市気温が低下寸ると、それに伴い冷房負荷が削減され、人工排熱 量も低下寸るといった間接的な効果も考えられる。ここでは夏期実 測結果を用いて、屋根面での熱収支を解析し、高反射率塗料の都市 気候への影響を検討する。

\section{1 熱収支式を用いた屋根面の熱収支解析 $\left.{ }^{5)}, 7\right)$, 8)}

以下に屋根面における熱収支式(図 12 参照)を示寸。

$R_{n}=V+L E+A$

$R_{n}=R_{S}+R_{L}=\left(1-\rho_{r}\right) J+\left(L_{a}-L_{e}\right)$

$A=-\lambda \frac{\partial T}{\partial x}$ 


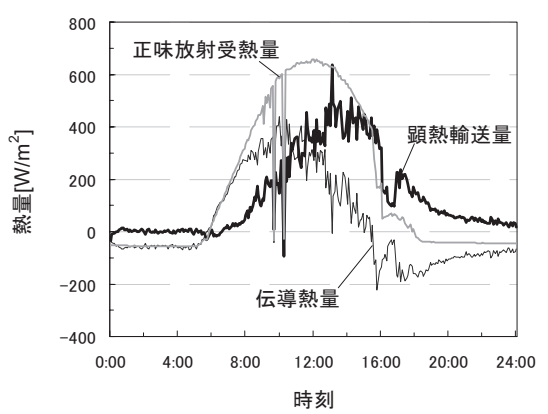

(a) 一般塗料塗布

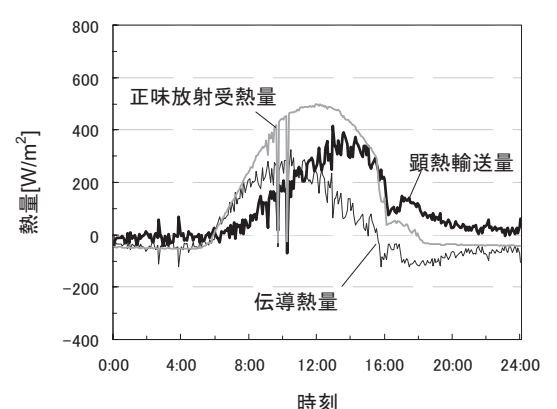

(b) 高反射率塗料塗布

図 13 屋根面における熱収支

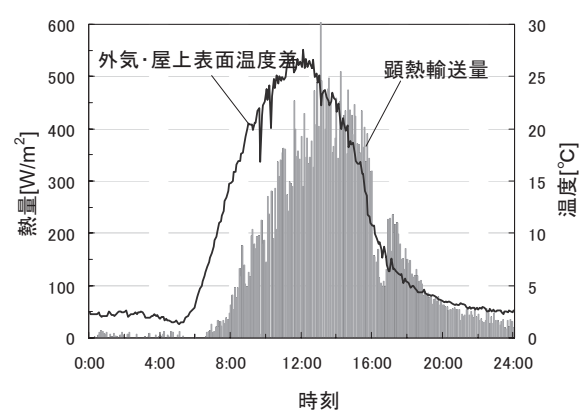

(a) 一般塗料塗布

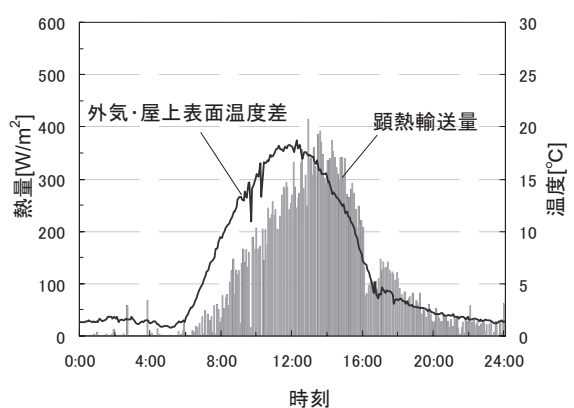

(b) 高反射率塗料塗布

図 15 顕熱輸送量と外気・屋上表面温度差

$$
\frac{\partial T}{\partial t}=\frac{\lambda}{C_{p} \rho} \frac{\partial^{2} T}{\partial x^{2}}
$$

まず、式(4)を離散化し前進差分法で解析し、屋上スラブ内温度 分布を求め注 2)、式(3)より屋上スラブ表面における伝導熱量 $A$ を算 出する。その際の境界条件として屋上スラブの屋外側表面温度と下 端表面温度の実測值を与える。次に日射量などの実測值を用いて式 (2)より正味放射受熱量 $R_{n}$ を算出し、式(1)より $A$ と $R_{n}$ の残差とし て顕熱輸送量 $V$ を求める。ただし夏期実測日は終日晴天であった ため、式(1)中の潜熱輸送量 $L E$ は 0 と仮定した。なお JIS R 3106 に 基づいて分光光度計により測定された日射反射率と、実測において 長短波放射計により測定した反射日射量から求めた日射反射率に差 異が生じた。これはJIS R 3106 では日射強度の波長分布として直達 日射のみを対象としていること等が影響しているものと考えられる。 ここでは日射反射率の值は実測結果(高反射率塗料: $\rho_{r}=0.40$ 、一般 塗料: $\left.\rho_{r}=0.21\right)$ を用いる。

\section{2 熱収支の計算結果}

(1) 顕熱輸送量の計算結果(図 13、14 参照)

図 13 に屋根面における熱収支の計算結果を、図 14 に屋根面にお ける顕熱輸送量を示す。伝導熱量の変化に着目すると、最大となる のは一般塗料、高反射率塗料ともに午前 11 時頃である。顕熱輸送 量に着目すると、日の出から 14 時 15 分頃にかけて徐々に増加し、 その後減少に転じる。この顕熱輸送量の日変化は外気温の日変化と 良く対応しており、熱収支解析の妥当性が確認できる。塗料別の顕 熱輸送量変化に着目すると、8 時以降の顕熱輸送量の増大とともに 一般塗料と高反射率塗料の差が大きくなる。日没後はその差が小さ くなるが、高反射率塗料のほうが小さい值となり、日中の建築躯体 への蓄熱低減が確認できる。また顕熱放散量の日積算値は一般塗料 が $11.7 \mathrm{MJ} / \mathrm{m}^{2}$ であるのに対し、高反射率塗料は $8.7 \mathrm{MJ} / \mathrm{m}^{2}$ で約 $26 \%$

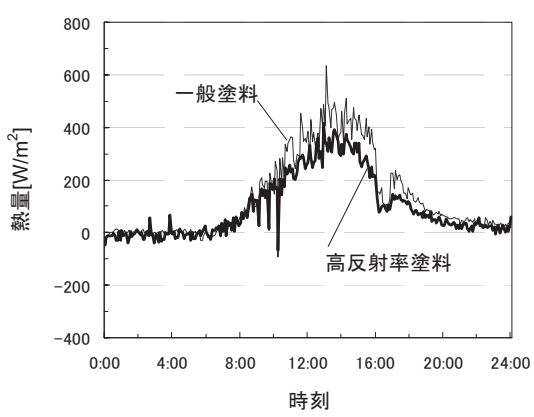

図 14 屋根面の顕熱輸送量

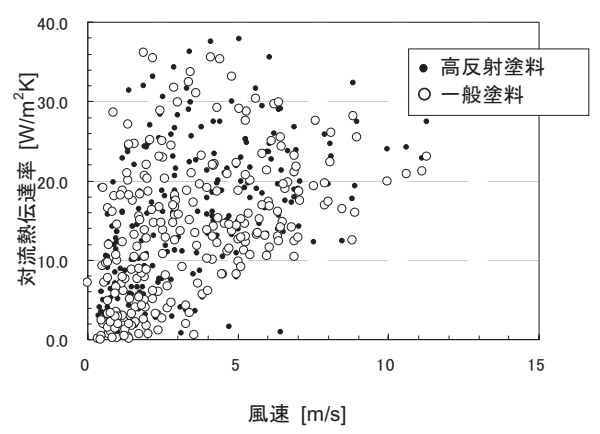

図 16 風速と対流熱伝達率の関係

小さくなり、顕熱放散削減量は $3.0 \mathrm{MJ} / \mathrm{m}^{2}$ となった。この值を用い、 東京 23 区の全ての屋根を高反射率化したと想定すると、睛天日に 削減される顕熱放散量は 23 区から排出される人工排熱量(建物+道 路交通+工場 $)^{9)}$ の約 $37 \%$ に相当すると試算される注 31 。ただし、ここ では隣接建物による日影の影響や屋上に設置されている設備機器な どの影響を無視している。また顕熱放散削減量は外気温、日射量、 風速などの気象条件により異なるため、常に人工排熱比 $37 \%$ の顕 熱放散削減が見込めるわけではない。

\section{（2）顕熱輸送量と外気・屋上表面温度差(図 15 参照)}

図 15 亿顕熱輸送量と外気・屋上表面温度差を示す。外気温と屋上 表面の温度差のピークは一般塗料、高反射率塗料ともに正午ごろで あり、顕熱輸送量のピークとは対応しない。

（3）風速と対流熱伝達率(図 16 参照)

図 16 に風速と対流熱伝達率の関係を示す。ここで対流熱伝達率 は、顕熱輸送量を同時刻の外気・屋上表面温度差で除して算出した。 図 16 からは対流熱伝達率と風速とは強い相関関係は確認できなか った。

\section{4 屋根面の反射日射による周辺建物への影響に関する CFD 解析}

高反射率塗料はヒートアイランド現象の緩和対策の一つとして考 えられるが、屋根面を高反射率化した場合、屋根面からの反射日射 が周辺建物の壁面などに吸収され冷房負荷増大につながることが懸 念される。ここでは CFD 解析を用いて上記の影響を検討する。

\subsection{CFD 解析概要}

図 17 に解析モデルを示す。ここでは低層建物屋根面から隣接建 物への反射日射の影響を考察するため、高層建物および低層建物が 混在した街区モデルを想定する。なお、解析モデルの対称性から $1 / 2$ 領域について解析を行い、解析日時は 8 月 19 日 12 時(太陽高 
度: $\left.66.8^{\circ}\right)$ とする。

\section{2 解析手法}

表 4 に地表面、建物壁面・屋根面の各面に与える条件を、表 5 に CFD 解析の条件を示す注 4 ) $\mathrm{CFD}$ 解析を行う前に、壁面などの固体 表面間の日射の相互反射を以下のように考慮し、壁面などの短波放 射受熱量の算出を行った。

(1) 表面要素 $i$ が受ける直達日射エネルギー $\left(E_{D i}\right)$

表面要素 $i$ が受ける直達日射エネルギー $E_{D i}$ は式(5)で表される。

$$
E_{D i}=A_{i} \cdot J_{D N} \cdot \sin (\theta+h)
$$

(表面要素 $i$ が水平面 : $h=0$ 、鉛直面 : $h=\pi / 2$ )

(2) 表面要素 $i$ が受ける天空日射エネルギー $\left(E_{S i}\right)$

表面要素 $i$ が受ける天空日射エネルギーは、表面要素 $i$ から天空 を臨む形態係数 $F_{i s}$ を用いて式(6)により求めた注5)。

$$
E_{S i}=A_{i} \cdot F_{i s} \cdot J_{S H}
$$

表面要素 $i$ が吸収する日射エネルギー $q_{D i}$ は式(7)により求められ る。

$$
q_{D i}=\alpha_{i}\left(E_{D i}+E_{S i}\right)
$$

(3) 相互反射を考慮した表面要素 $i$ の短波放射受熱量 $\left(q_{R S, i}\right)$

各面が完全拡散面であると仮定し、表面要素 $j$ から表面要素 $i$ 一
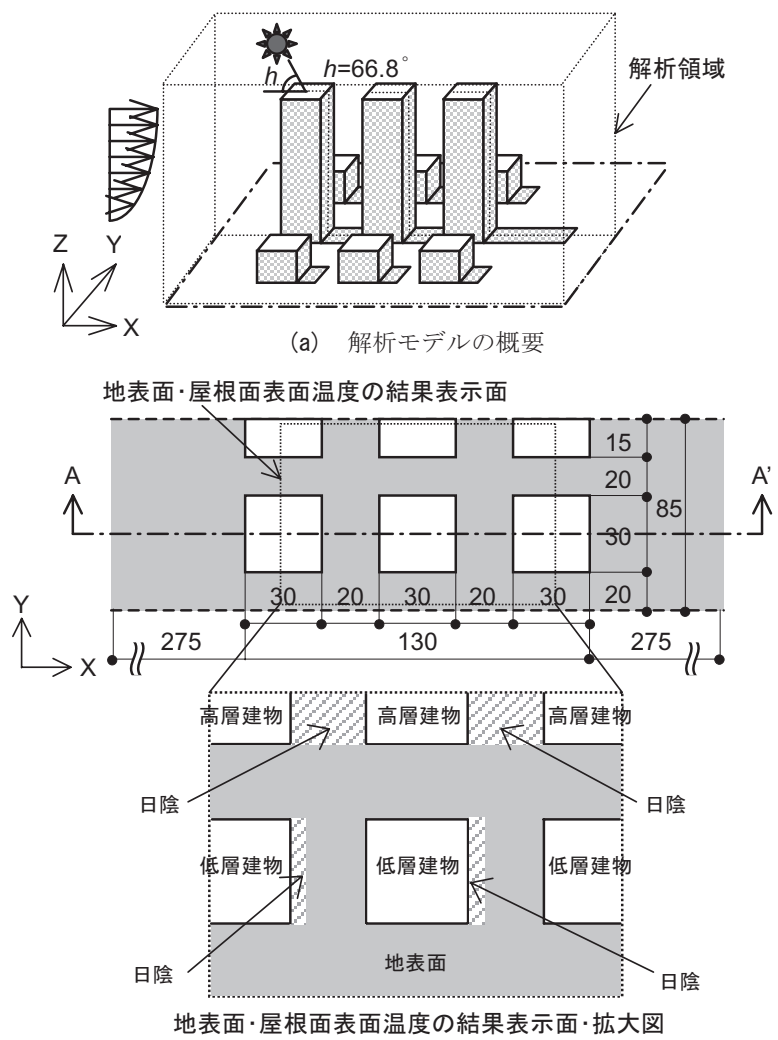

(b) 平面図 単位: [m]

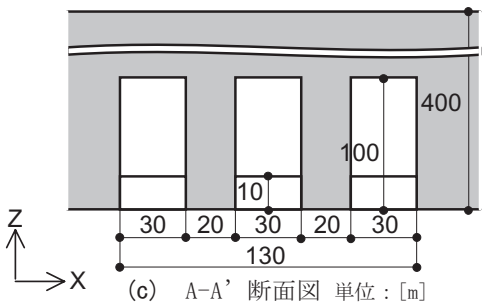

図 17 解析モデル
の反射日射量は Gebhart の吸収係数 $B_{j i}$ を用いて式(8)より求められ る注 5)。

$$
q_{A j i}=B_{j i} \cdot\left(1-\alpha_{j}\right)\left(E_{D j}+E_{S j}\right)
$$

以上より、相互反射を考慮した表面要素 $i$ への短波受熱量 $q_{R S, i}$ は 式(9)より求められる。

$$
q_{R S, i}=q_{D i}+\sum_{j=1}^{n} q_{A j i}
$$

上式で求めた $q_{R S, i}$ を舗装面、壁面の各面に発熱量として CFD 解 析の境界条件として与えた。一方、長波放射授受は、対流・放射連 成 CFD 解析により各面の表面温度を求める際に組み込まれる。そ

\begin{tabular}{|c|c|c|c|c|}
\hline \multirow{2}{*}{ 項目 } & \multicolumn{2}{|c|}{ 舗装面 } & \multicolumn{2}{|c|}{ 建物壁面·屋根面 } \\
\hline & (1)日照部 & (2)日影部 & (3)日照部 & (4)日影部 \\
\hline \multirow{2}{*}{ 日射(短波) } & $\begin{array}{l}\text { 直達日射 } \\
\text { 天空日射 }\end{array}$ & 天空日身 & $\begin{array}{l}\text { 直達日射 } \\
\text { 天空日射 }\end{array}$ & 天空日射 \\
\hline & \multicolumn{4}{|c|}{$\begin{array}{l}\text { 法線面直達日射量: } 811.6\left[\mathrm{~W} / \mathrm{m}^{2}\right] \\
\text { 水平面天空日射量 : } 144.9\left[\mathrm{~W} / \mathrm{m}^{2}\right]\end{array}$} \\
\hline 反射日射(短波) & \multicolumn{4}{|c|}{$\begin{array}{c}\text { 壁·舗装面間の相互反射を考慮した受熱量を } \\
\text { 事前に算出し、等量として規定 }\end{array}$} \\
\hline 大気放射(長波) & \multicolumn{4}{|c|}{ 天空面に仮想天空温度 $T_{s k v}$ を規定 : $\left.25.9{ }^{\circ} \mathrm{C}\right]$} \\
\hline 裏面条件 & \multicolumn{4}{|c|}{\begin{tabular}{c|cc} 
舗装面より $100[\mathrm{~mm}]$ 下の & 建物内部に空調室温度を夫 \\
\end{tabular}} \\
\hline 対流熱伝達率 & \multicolumn{4}{|c|}{$\begin{array}{l}\text { ユルゲスの実験式(滑面) } \\
\text { ( }\end{array}$} \\
\hline
\end{tabular}
の際、天空面に規定する仮想天空温度 $T_{s k y}$ は、Brunt の式より求め た。人工排熱は、低層建物では壁面排出、高層建物では屋根面排出、

\begin{tabular}{|c|c|c|}
\hline 解析領域 & \multirow{2}{*}{\multicolumn{2}{|c|}{ 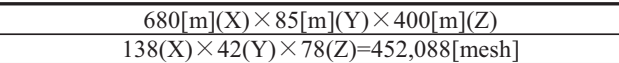 }} \\
\hline メッシュ分割 & & \\
\hline 乱流モデル & \multicolumn{2}{|c|}{ 標準 $k-\varepsilon$ モデル } \\
\hline 流入条件 & \multicolumn{2}{|c|}{ 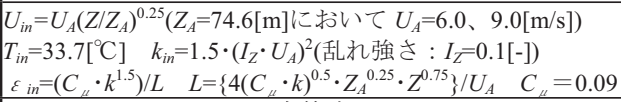 } \\
\hline 流出条件 & \multicolumn{2}{|c|}{ 自然流出 } \\
\hline 壁面応力条件 & \multicolumn{2}{|c|}{ 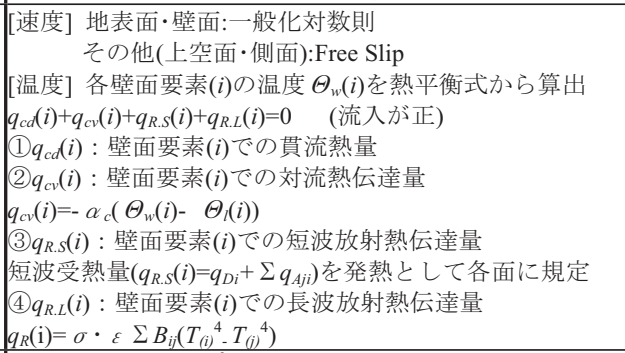 } \\
\hline $\begin{array}{l}\text { 人工排熱および } \\
\text { 排出位直 } 9 \text {,10,,11) }\end{array}$ & \multicolumn{2}{|c|}{ 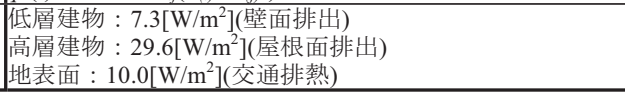 } \\
\hline \multicolumn{3}{|c|}{ 表 6 解析ケース } \\
\hline Case & $\begin{array}{l}\text { 基隻高さ } Z_{A} \text { に } \\
\text { おける風速 } U_{A} \\
\end{array}$ & 屋根面の状態 \\
\hline Case 1 & \multirow{2}{*}{$6.0[\mathrm{~m} / \mathrm{s}]$} & $\begin{array}{c}\text { 一般塗料 } \\
\text { (日射反射率 : } 21.0[\%] \text { ) }\end{array}$ \\
\hline Case 1-H & & $\begin{array}{c}\text { 高反射率塗料 } \\
\text { (日射反射率 : } 40.0[\%] \text { ) }\end{array}$ \\
\hline Case 2 & \multirow{2}{*}{$9.0[\mathrm{~m} / \mathrm{s}]$} & 一般塗料 \\
\hline $\begin{array}{ll}\text { Case } 2-\mathrm{H} \\
\end{array}$ & & 高反射率塗料 \\
\hline \multicolumn{3}{|c|}{ ※舗装面の日射反射率 : 7.4[\%] $]^{\text {注 } 6)}$} \\
\hline \multicolumn{3}{|c|}{ 表 7 各面における対流熱伝達率の想定値(ユルゲスの式による) } \\
\hline 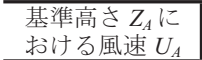 & $\begin{array}{c}\text { 地表面·低層建物屋根面 } \\
\text { の対流熱云達率 }\end{array}$ & その他の面の対流熱伝達率 \\
\hline $6.0[\mathrm{~m} / \mathrm{s}]$ & \multirow{2}{*}{$\begin{array}{c}19.6\left[\mathrm{~W} / \mathrm{m}^{2} \cdot \mathrm{K}\right] \\
26.1\left[\mathrm{~W} / \mathrm{m}^{2} \cdot \mathrm{K}\right]\end{array}$} & $25.7\left[\mathrm{~W} / \mathrm{m}^{2} \cdot \mathrm{K}\right]$ \\
\hline $9.0[\mathrm{~m} / \mathrm{s}]$ & & $35.2\left[\mathrm{~W} / \mathrm{m}^{2} \cdot \mathrm{K}\right]$ \\
\hline
\end{tabular}
交通排熱は地表面排出とし、各面における発熱量として規定した。

表 4 地表面、建物壁面・屋根面の各面に与える条件注 4$)$

表 5 解析条件注 4$)$ 


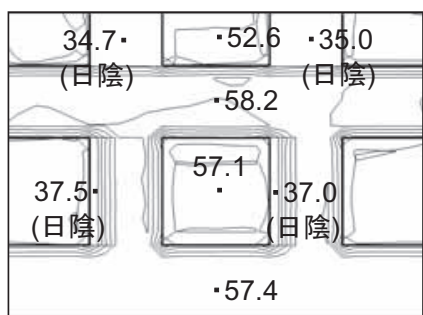

(a) Case $1\left(U_{A}=6 \mathrm{~m} / \mathrm{s}\right)$ $\stackrel{Y}{\Lambda}$

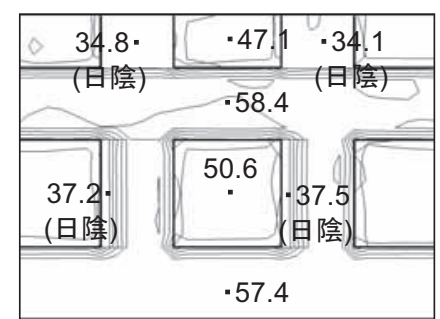

(b) Case 1-H $\left(U_{A}=6 \mathrm{~m} / \mathrm{s}\right)$

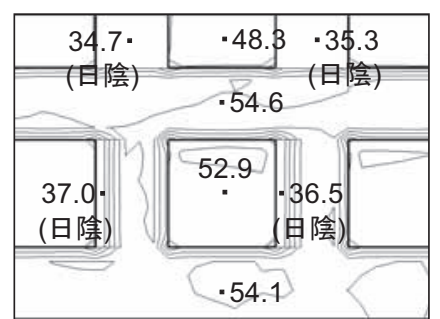

(c) Case $2\left(U_{A}=9 \mathrm{~m} / \mathrm{s}\right)$

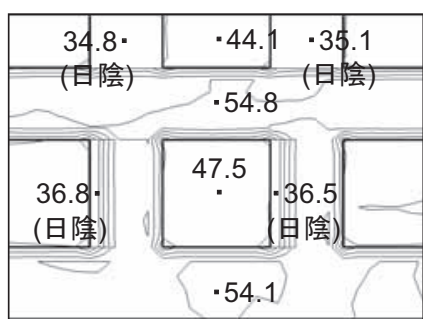

(d) Case $2-\mathrm{H}\left(U_{A}=9 \mathrm{~m} / \mathrm{s}\right)$

図 18 地表面・屋根面表面温度 単位: $\left[{ }^{\circ} \mathrm{C}\right]$

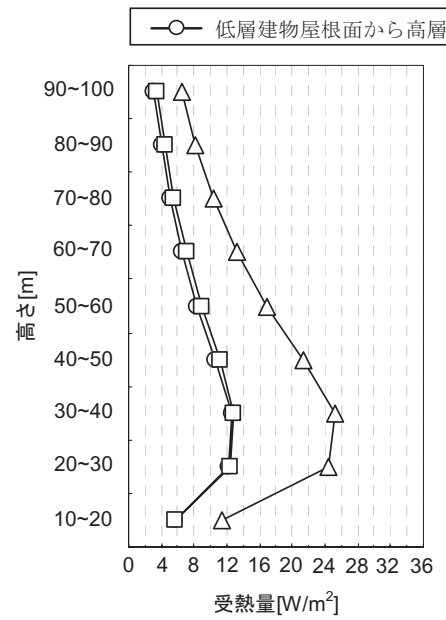

(a) Case $1\left(U_{A}=6 \mathrm{~m} / \mathrm{s}\right)$

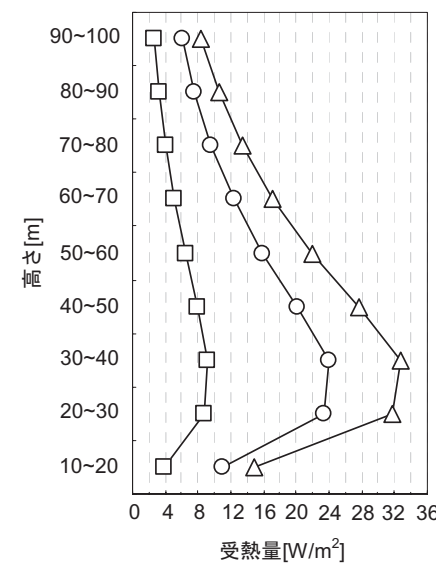

(b) Case 1-H $\left(U_{A}=6 \mathrm{~m} / \mathrm{s}\right)$

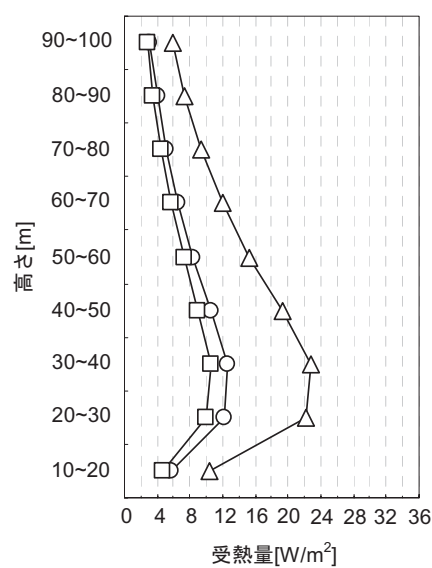

(c) Case $2\left(U_{A}=9 \mathrm{~m} / \mathrm{s}\right)$

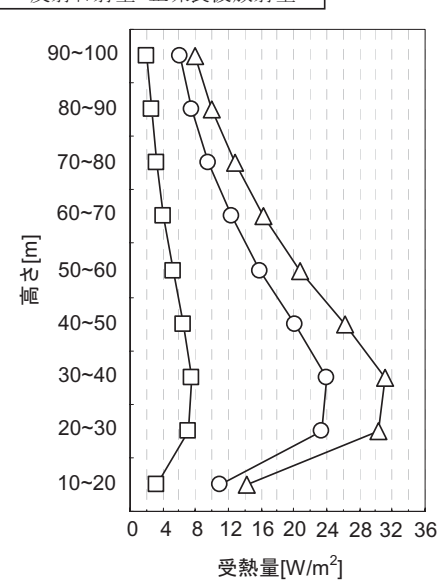

(d) Case $2-\mathrm{H}\left(U_{A}=9 \mathrm{~m} / \mathrm{s}\right)$

図 19 低層建物屋根面から高層建物壁面への反射日射量および長波放射受熱量

(3つの高層建物の平均值、高層建物壁面への受熱を正とする)

\section{3 解析ケース}

表 6 に解析ケースを、各ケースの対流熱伝達率を表 7 に示す。屋 根面が一般塗料の場合と高反射率塗料の場合を考え、基準高さ $Z_{A}\left(\right.$ 本報では $74.6 \mathrm{~m}$ )における風速 $U_{A}$ をそれぞれ $6.0 \mathrm{~m} / \mathrm{s} 、 9.0 \mathrm{~m} / \mathrm{s}$ とし た場合の 2 ケースを想定する。

\section{4 解析結果}

\section{(1) 地表面·屋根面表面温度(図 18 参照)}

地表面と屋根面の温度を図 18 に示す。 $U_{A}$ が $6.0 \mathrm{~m} / \mathrm{s}$ の場合、高反 射率塗料の場合の方が低層屋根面表面温度は最大約 $6.5^{\circ} \mathrm{C}$ 低く、高 層建物屋根面は約 $5.5^{\circ} \mathrm{C}$ 低くなっており、表面温度の上昇が抑えら れている。

$U_{A}$ が $9.0 \mathrm{~m} / \mathrm{s}$ になると、 $U_{A}$ が $6.0 \mathrm{~m} / \mathrm{s}$ の場合に比べ、対流熱伝達率 が大きくなるため、一般塗料と高反射率塗料との差は小さくなり、 その差は低層屋根面において最大約 $5.4^{\circ} \mathrm{C}$ 、高層屋根面において約 $4.2^{\circ} \mathrm{C}$ さらに小さくなる。このように、 $U_{A}$ の值によって差がある が、全てのケースにおいて高反射率塗料の効果が確認できる。

\section{（2）低層建物屋根面から高層建物壁面への反射日射量と正味長波} 放射量(図 19 参照)

低層建物屋根面 $(\mathrm{GL}+10 \mathrm{~m})$ から隣接する高層建物壁面への反射日 射量および正味長波放射量を図 19 に示す。全てのケースにおいて、 低層建物屋根面から高層建物壁面一の反射日射量と正味長波放射量 は、高さ30 40m で最大值を示す。

一般塗料と高反射率塗料を比較すると、低層建物屋根面から高層 建物壁面への反射日射量は高反射率塗料の場合の方が高く、正味長
波放射量は高反射率塗料の方が低い。また、反射日射量と正味長波 放射量の和は高反射率塗料の場合の方が一般塗料より高く、その差 は高さ30 40m において、 $U_{A}$ が $6.0 \mathrm{~m} / \mathrm{s}$ の場合で $7.6 \mathrm{~W} / \mathrm{m}^{2} 、 U_{A}$ が $9.0 \mathrm{~m} / \mathrm{s}$ の場合で $8.3 \mathrm{~W} / \mathrm{m}^{2}$ 程度である。しかし、本解析で想定した鉛 直面での天空日射量は約 $72 \mathrm{~W} / \mathrm{m}^{2}$ であり、これと比較すると高反射 率化した建物屋根面から周囲への建物への影響は小さいと考えられ る。

\section{5 結論}

建物屋根面の日射反射性能を向上させた場合のヒートアイランド 緩和効果を夏期実測、熱収支解析および CFD 解析の結果により検 討した。

（1）夏期に行った実測において、高反射率塗料を塗布した屋上表 面温度は一般塗料を塗布した屋上面と比較して最大約 $10^{\circ} \mathrm{C}$ 低 くなり、日中の温度上昇が大きく抑制された。

(2) 夏期実測結果を用いて、屋根面における熱収支解析を行った。 高反射率塗料を屋根面に塗布した場合、正味放射受熱量 $R_{n}$ の 削減に伴い、屋根面から都市大気への顕熱放散量 $V$ が減少し た。

(3) CFD 解析により、屋根面からの反射日射による隣接建物壁面 への影響を検討した。低層建物屋根面を高反射率化した場合、 隣接建物への反射日射の影響はあるものの、天空日射量など に比べるとかなり小さい。

以上の結果から、高反射率塗料のヒートアイランド現象緩和効果 
(http://www.metro.tokyo.jp/)に示されている值を用いた。

\section{謝 辞}

高反射率塗料および一般塗料の日射反射率の測定を(財)建材試験 センターに、舗装面の日射反射率の測定を(株)日本ペイントにお願 いした。また、計測機器を大成建設(株)、東急建設(株)、三井住建 道路(株)よりお借りした。実測では、鹿児島大学・長澤康弘氏(当時、 武蔵工業大学技術員)、小山田早希子氏(当時、武蔵工業大学学生)、 天明望氏(同)をはじめとする多くの方々に協力を賜った。ここに記 して、謝意を表します。

\section{参考文献}

1) 近藤·長澤·入交:高反射率塗料による日射熱負荷軽減とヒートアイランド現象 緩和に関する研究:空気調和・衛生工学会論文集 No.78, pp.15-24.2000 年 7 月

2) 近藤·長澤·大南:黒色高反射率塗料に上る住宅屋根の日射反射性能の向上:日本 建築学会大会学術講演㤦概集(北陸)D-2 環境工学 II, pp.117-118. 2002 年 8 月

3) 近藤·大木 光本: 実測による高反射率塗料の遮熱性能に関する研究: 日本建築学 会大会学術講演梗概集(近畿)D-2 環境工学 II, pp.261-262. 2005 年 9 月

4) 近藤·大木:実測と数值シミュレーションによる高反射率塗料の遮熱性能に関す 万研究:空気調和·衛生工学会大会学術講演論文集(札幌), pp.217-220. 2005 年 8 月

5)竹林·森山·野上ら:屋上緑化及び高反射塗料の表面熱収支結果: 日本建築学会学 術講演梗概集(近畿) D-2 環境工学 II, pp.41-44.2005 年 9 月

6) 西村·松尾·三木·村瀬:太陽熱高反射塗装の日射熱防除効果: 日本建築学会学術 講演梗概集(東海)D-2 環境工学II, pp.377-378. 2003 年 9 月

7) 近藤純正:地表面に近い大気の科学:東京大学出版会 2000 年 9 月

8) 近藤純正:水環境の気象学:朝倉書店 1994 年 4 月

9）足永・李·尹䨅熱潜熱の違いを考慮した東京 23 区における人工排熱の排出特性に 関する研究:空気調和·衛生工学会論文集 No.92, pp.121-130. 2004 年1月

10）萩島·谷本・片山・宮原:建物空調排熱位置及び都市形状の実態に関する調 查:日本建築学会環境系論文集 第567号, pp.65-72. 2003年5月

11) 陳・大岡・黄・中嶋:建物壁面からの顕熱放散や建物の人工排熱の屋外温熱 環境に関する影響度の研究(その 1)(その 2)屋外温熱環境への影響度の概 要と均一市街地一の適用:空気調和·衛生工学会大会学術講演論文集(札 幌), pp.2197-2204. 2005 年 8 月

\section{注}

注1) 高反射率塗料および一般塗料ともに灰色(N60)とした。分光反射率 の測定はJIS R 3106 に基づき、波長 300 2500[nm]での分光反射率(正 反射十拡散反射)を測定し、日射強度分布に重夕付け平均することで 日射反射率の測定を行った。また長波放射率の測定はフーリエ変換赤 外分光光度計((株)島津製作所:FT-IR)を用いて行った。なおこれらの測 定は(財)建材試験センターに実施いただいた。

注2)実測対象建物は竣工後相当年経過しており、詳細図が無かったため スラブ厚は推定值 $(200[\mathrm{~mm}])$ とした。なお、断熱材は施工されていな い。また熱流計により屋上スラブ面の熱流を測定したが、充分な精度 の結果が得られなかった。このため、式(3)、(4)により伝導熱量 $A$ を 求めた。

注3）本報では、「各区の面積に対する建物の全屋根面積の割合」=「グ ロス建蔽率」と仮定し、各区面積にグロス建蔽率を乗じて高反射率塗 料を塗布する総面積を計算した。ここで、グロス建蔽率とは各地区の 面積に対する建物投影面積の割合であり、東京都公式ホームページ
注4) 日射量・地面裏面の内部温度(GL-200mm) 仮想天空温度を求める際 の大気放射量、外気温(流入空気温度)は別途行った道路舗装面に関す る夏季実測(2006 年 8 月 19 日 12 時)における実測值を用いている。全 天日射・地面裏面の内部温度については 12 時〜 14 時の平均值を用い た。

注5) 本報では Gebhart の吸収係数 $B_{i j}$ はモンテカルロ法を用いて算出し た。図 17 に示寸街区モデルの固体表面を表面要素に分割し、各面要 素から粒子を発生させ、追跡する。粒子がある固体表面に到達した場 合、0から 1 の乱数を発生させ、乱数が放射率以下であれば吸収、放 射率以上であれば反射させ、反射の方向はランバートの法則(乱反射) によるものとする。最大反射回数を 100 回とし、 $i$ 面から発生させた 粒子のうち最終的に $j$ 面に吸収された粒子数を集計して、 $i$ 面の発生 粒子数との比を $B_{i j}$ とした。天空率も同様に求めた。ただし、鉛直壁 面で対向する位置に他の壁面などがない場合において、天空率が 0.5 とならない場合があったが、この場合は天空率を 0.5 とした。なお、 天空率を求める際は全ての面の放射率を 1.0 とし、Gebhart の吸収係 数を求める際は一般塗料面の放射率を 0.79 、高反射率塗料面で 0.60 、 地表面で 0.93 、天空で 1.0 とした。

注6)舗装面の日射反射率は(株)日本ペイントで測定されたものを提供し ていただいた。

[記 号 表]

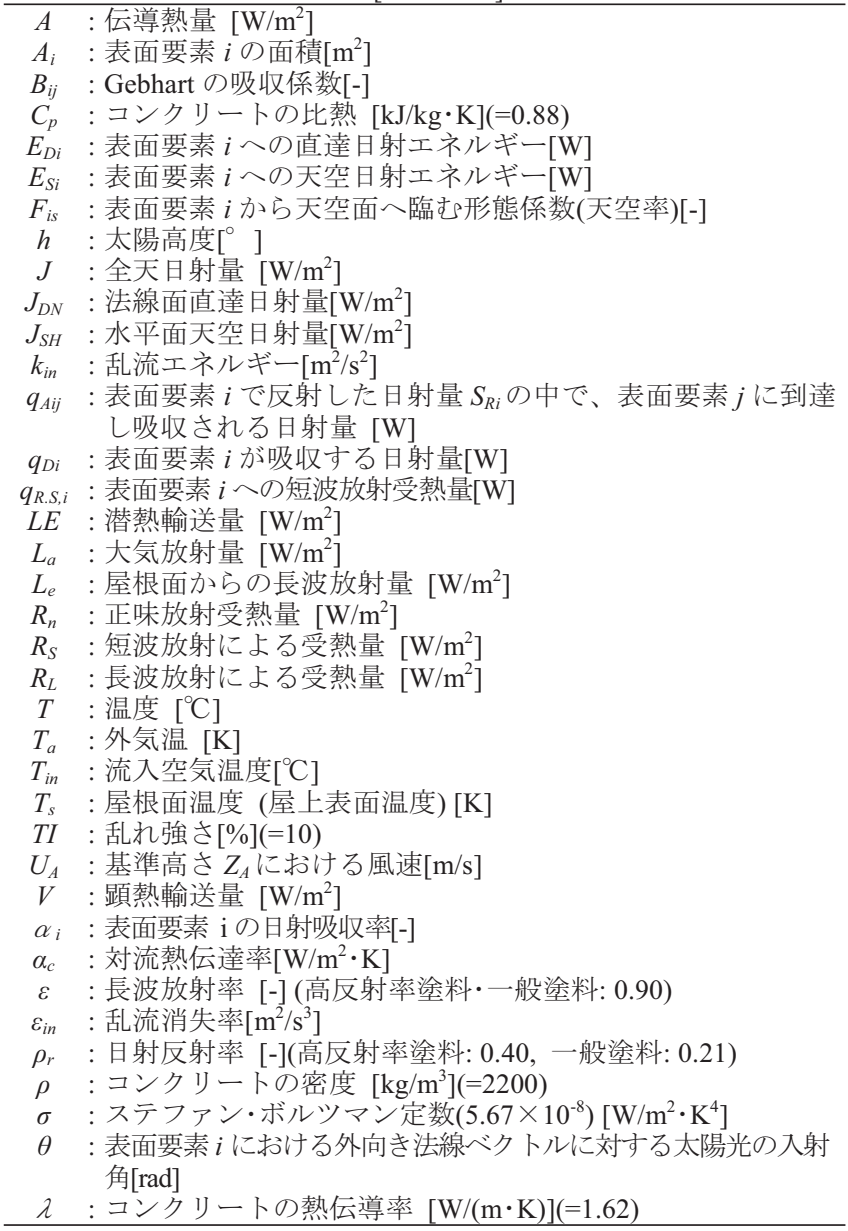

（2007年12月10日原稿受理，2008年 4 月 7 日採用決定） 